\title{
KESALAHAN PEMAKAIAN TANDA BACA PADA WAHANA FKIP VOLUME 62 NOMOR 1 TAHUN 2014 UNIVERSITAS PGRI ADI BUANA SURABAYA
}

\author{
Murtianingsih Dwi Iryanti, Taufik Nurhadi \\ Pendidikan bahasa dan sastra indonesia, Fakultas Keguruan dan Ilmu Pendidikan, \\ Universitas PGRI Adi Buana Surabaya \\ murtianingsihunipa@gmail.com, taufiknurhadi70@gmail.com
}

\begin{abstract}
ABSTRAK
Penelitian ini bertujuan untuk mendeskripsikan penggunaan tanda baca yang salah pada buku WAHANA FKIP Universitas Adi Buana PGRI Surabaya. Penelitian ini merupakan penelitian perspektif kualitatif. Subyek dalam penelitian ini adalah buku WAHANA FKIP Universitas Adi Buana PGRI Surabaya. Objek penelitian ini adalah seluruh bentuk penggunaan tanda baca yang salah pada buku WAHANA FKIP Universitas Adi Buana PGRI Surabaya. Tentang hal ini dianalisis penelitian tentang kesalahan tanda baca pada buku FKIP Universitas Adi Buana PGRI Surabaya. Dalam penelitian ini kami menggunakan teknik belajar dan membuat catatan. Permasalahan yang diteliti adalah salah satunya melalui penggunaan Tanda Baca yang Salah Dalam Buku WAHANA Jilid 62 Nomor 1 Tahun 2014 FKIP Universitas Adi Buana PGRI Surabaya. Keabsahan penelitian ini menggunakan teknik triangulasi teori, karena merupakan penelitian analisis. Dari penelitian yang telah dilakukan Terdapat 64 Tanda Baca Salah Di WAHANA FKIP Volume 62 Nomor 1 Tahun 2014 Universitas Adi Buana PGRI Surabaya. (1) tanda baca titik (.); (2) koma (,); (3) tanda titik dua (:); (4) tanda hubung (-); (5) tanda baca kurung (()); dan (6) tanda baca garis miring (/).
\end{abstract}

Kata kunci: Wahana, Tanda Baca dan Bahasa.

\section{PENDAHULUAN}

Bentuk bahasa adalah bahasa lisan dan bahasa tulis. Bahasa yang akan penulis analisis atau dikaji ialah bahasa tulis yang ditranskrip dalam bentuk tulisan, sehingga bahasa tersebut harus dibaca dan memerlukan keberadaan antara seorang penulis dengan pembaca.

Bermacam-macam bentuk bahasa tulis maka peneliti memilih wahana FKIP sebagai objek yang dikaji. Wahana FKIP ialah sebuah bentuk artikel yang memuat informasi atau berita mengenai Universitas PGRI Adi Buana Surabaya. Pemakaian bahasa pada jurnal atau artikel berkaitan dengan kebakuan bahasa Indonesia. Oleh karena itu, penulisan artikel atau jurnal yang dimuat atau ditulis dan bersifat resmi atau formal harus ditulis dengan syarat-syarat kebakuan.

Bahasa Indonesia sebagai alat komunikasi dipakai dalam berbagai keperluan tentu tidak seragam, tetapi akan berbeda-beda disesuaikan dengan situasi dan kondisi. Keanekaragaman penggunaan bahasa Indonesia itulah yang dinamakan ragam bahasa Indonesia (Kuntarto, 2013: 4).

Ejaan mempunyai peranan yang cukup besar dalam sebuah tulisan. Dalam penulisan artikel ilmiah, masalah ejaan harus diperhatikan dengan sungguhsungguh (Mustakim, 1992). Ejaan mengatur keseluruhan cara menuliskan bahasa dengan menggunakan huruf, kata, dan tanda baca sebagai sarananya. Ejaan merupakan kaidah yang harus dipatuhi oleh pemakai bahasa demi keteraturan dan 
keseragaman bentuk, terutama dalam bahasa tulis. Keteraturan bentuk berimplikasi pada ketepatan dan kejelasan makna (Finoza, 2005:13).

Kata pungtuasi berasal dari kata Yunani "Punctus" yang berarti "poin". Pungtuasi atau tanda-tanda baca sebagai hasil usaha menggambarkan unsur-unsur suprasegmental itu tidak lain dari gambar-gambar atau tanda-tanda yang secara konvensional disetujui bersama untuk memberi kunci kepada pembaca terhadap apa yang ingin disampaikan kepada mereka (Keraf, 2004: 14-15).

\section{METODE PENELITIAN}

Dalam menganalisis penelitian ini, penulis menggunakan metode penelitian kualitatif yang bersifat preskriptif. Basrowi \& Suwandi (2008: 21) mengatakan bahwa istilah penelitian kualitatif dimaksudkan sebagai jenis penelitian yang temuan-temuannya tidak diperoleh melalui prosedur statistik atau bentuk hitungan lain.

Dalam penelitian kualitatif segala sesuatu yang akan dicari dari objek penelitian belum jelas masalahnya, sumber datanya, hasil yang diharapkan semuanya belum jelas. Rancangan penelitian masih bersifat sementara dan akan berkembang setelah peneliti memasuki obyek penelitian. Selain itu dalam memandang ralitas, peneliti kualitatif berasumsi bahwa realitas itu bersifat holistik (menyeluruh), dinamis, tidak dapat dipisah-pisahkan kedalam variabel-variabel penelitian. Kalaupun dapat dipisah-pisahkan, variabelnya akan banyak sekali. Dengan demikian dalam penelitian kualitatif ini belum dapat dikembangkan intrumen penelitian sebelum masalah yang diteliti jelas sama sekali. Oleh karena itu, penelitian kualitatif "the researcher is the key instrument". Jadi peneliti adalah merupakan instrumen kunci dalam penelitian kualitatif (Sugiyono, 2013:223).

\section{PEMBAHASAN}

\section{Artikel Pertama}

a. Kesalahan Pemakaian Tanda Titik (.)

Dari hasil pengamatan berdasarkan data yang diperoleh dalam pemakaian tanda baca titik (.) pada wahana artikel pertama, ditemukan kesalahan penulisan tanda baca titik (.) sebagai berikut:

$>$ "Nazir, Mohammad (1999), Metode Penelitian Edisi Keempat, Penerbit Ghalia Indonesia, Jakarta"(Widyastuty, 2014:13).

Dari data diatas terdapat kesalahan pemakaian tanda baca titik (.) dalam penulisan daftar pustaka, yaitu terletak di tengah setelah penulisan nama penulis seharusnya memakai tanda titik bukan tanda kurung. Sehingga dalam penulisan EYD seharusnya "Nazir, Muhammad. 1999. Metode Penelitian Edisi Keempat. Jakarta: Penerbit Ghalia Indonesia".

b. Kesalahan Pemakaian tanda Koma (,)

Dari hasil pengamatan berdasarkan data yang diperoleh dalam pemakaian tanda baca koma (,) pada wahana, ditemukan kesalahan penulisan tanda baca koma (,). Tanda baca koma (,) atau perhentian sejenak antara yang menunjukkan suara menaik di tengah-tengah tutur. Adapun kegunaan koma yaitu:

$>$ "Fenomena yang terjadi saat ini adalah, banyak calon penumpang dan penumpang yang naik dan turun dr mobil angkutan umum berada di luar 
terminal sehingga dapat menyebabkan macet, dan rawan kecelakaan." (Widyastuty, 2014:1)

Dalam kutipan diatas terdapat kesalahan dalam pemakaian tanda titik setelah kata adalah, dalam penulisan tersebut tidak seharusnya memakai tanda koma. Jadi, tanda koma diatas dihilangkan. Penulisannya yang sesuai dengan EYD adalah "Fenomena yang terjadi saat ini adalah banyak calon penumpang dan penumpang yang naik dan turun dari mobil angkutan umum berada di luar terminal sehingga dapat menyebabkan macet, dan rawan kecelakaan."

c. Kesalahan Pemakaian Tanda titik dua (:)

Dari hasil pengamatan berdasarkan data yang diperoleh dalam pemakaian tanda baca titik dua (:) pada wahana, ditemukan kesalahan penulisan tanda baca titik dua (:) sebagai berikut:

$>$ "Nazir, Mohammad (1999), Metode Penelitian Edisi Keempat, Penerbit Ghalia Indonesia, Jakarta" (Widyastuty, 2014:13).

Dalam kutipan diatas pemakaian tanda baca titik dua terletak pada penulisan kota penerbit dan penerbit. Tanda titik dua biasanya dipakai diantara (a) jilid atau nomor dan halaman, (b) bab dan ayat dalam kitab suci, (c) judul dan anak judul suatu karangan, serta (d) nama kota dan penerbit buku acuan dalam karangan. Sehingga bentuk penulisasn yang sebenarnya adalah "Nazir, Mohammad. 1999.Metode Penelitian Edisi Keempat. Jakarta: Penerbit Ghalia Indonesia."

d. Kesalahan Pemakaian Tanda Kurung (())

Dari hasil pengamatan berdasarkan data yang diperoleh dalam pemakaian tanda baca kurung (()) pada wahana, ditemukan kesalahan penulisan tanda baca kurung (()). Adapun beberapa macam penggunaan tanda baca kurung (()) di bawah ini:

$>$ "Nazir, Mohammad (1999), Metode Penelitian Edisi Keempat, Penerbit Ghalia Indonesia, Jakarta" (Widyastuty, 2014:13).

Dalam pemakaian tanda kurung diatas terdapat kesalahan penempatan. Pemakaian tanda kurung tidak seharusnya dipakai dalam penulisan tahun pada daftar pustaka. Karena penulisan yang seharusnya ialah tanda kurung dihilangkan sehingga penulisan yang benar adalah Nazir, Mohammad. 1999. Metode Penelitian Edisi Keempat. Jakarta: Penerbit Ghalia Indonesia.

e. Kesalahan Pemakaian Tanda Baca Garis Miring (/)

Dari hasil penelitian pada wahana FKIP terdapat kesalahan pemakaian tanda baca garis miring (/). Berikut beberapa penggunaan garis miring (/) akan dijelaskan di bawah ini:

$>$ "Tipe A, berfungsi melayani kendaraan untuk aangkutan umum atau antar kota daan antar propinsi (AKAP) dan/atau angkutan lintas batas negara, angkutan antar kota dalam propinsi (AKDP), angkutan dalam kota (ADK) dan angkutan pedesaan (ADES)". (Widyastuty, 2014:2)

Dalam kutipan diatas terdapat kesalahan pemakaian tanda garis miring (/) yaitu terletak pada "dan/atau". Jika ditulis "dan/atau" maka memiliki arti jamak dan pemborosan kata. Karena jika dibaca oleh pembaca maka "dan per atau", sehingga penulisan yang benar adalah harus dipilih salah satu yang sesuai dengan kalimat. 


\section{Artikel Kedua}

a. Kesalahan Pemakaian Tanda Titik (.)

Dari hasil pengamatan berdasarkan data yang diperoleh dalam pemakaian tanda baca titik (.) pada wahana artikel pertama, ditemukan kesalahan penulisan tanda baca titik (.) sebagai berikut:

$>$ "Melakukan validasi terhadap perangkat pembelajaran" (Ladyawati dan Oktavia, 2014:20).

Pada akhir kalimat di atas tidak ditemukan tanda baca titik, yang seharusnya terdapat tanda baca titik di akhir kalimat. Tanda titik dipakai pada akhir kalimat yang bukan pertanyaan atau seruan. Maka hal tersebut merupakan suatu kesalahan. Kalimat di atas dapat dibenarkan dengan cara memberi tanda baca titik di akhir kalimat. Penulisan yang seharusnya ialah "Melakukan validasi terhadap perangkat pembelajaran."

b. Kesalahan Pemakaian Tanda Titik Dua (:)

Dari hasil pengamatan berdasarkan data yang diperoleh dalam pemakaian tanda baca titik dua (:) pada wahana, ditemukan kesalahan penulisan tanda baca titik dua (:) sebagai berikut:

$>$ "Muslich, Masnur. 2007. KTSP Dasar Pemahaman Dan Pengembangan .Jakarta : Bumi Aksara". (Ladyawati dan Oktavia, 2014:23)

Pada kutipan selanjutnya ditemukan kesalahan pemakaian tanda baca titik dua karena penulisan yang seharusnya tanda baca titik dua terletak setelah kata bertujuan tanpa menggunakan spasi. Sehingga bentuk pembenaran yang sesuai dengan EYD ialah "Muslich, Masnur. 2007. KTSP Dasar Pemahaman Dan Pengembangan . Jakarta: Bumi Aksara."

\section{Artikel Ketiga}

a. Kesalahan Pemakaian Tanda Titik (.)

Dari hasil pengamatan berdasarkan data yang diperoleh dalam pemakaian tanda baca titik (.) pada wahana artikel pertama, ditemukan kesalahan penulisan tanda baca titik (.) sebagai berikut:

> "Presepsi masyarakat terhadap pengelolaan sampah" (Rohmadiani, 2014:26).

Pada akhir kalimat di atas tidak ditemukan tanda baca titik, yang seharusnya terdapat tanda baca titik di akhir kalimat. Tanda titik dipakai pada akhir kalimat yang bukan pertanyaan atau seruan. Maka hal tersebut merupakan suatu kesalahan. Kalimat di atas dapat dibenarkan dengan cara memberi tanda baca titik di akhir kalimat. Penulisan yang seharusnya ialah "Presepsi masyarakat terhadap pengelolaan sampah."

b. Kesalahan Pemakaian Tanda Koma (,)

Dari hasil pengamatan berdasarkan data yang diperoleh dalam pemakaian tanda baca koma (,) pada wahana, ditemukan kesalahan penulisan tanda baca koma (,). Tanda baca koma (,) atau perhentian sejenak antara yang menunjukkan suara menaik di tengah-tengah tutur. Adapun kegunaan koma yaitu:

> "Oleh karena itu peran masyarakat disini hanya clients atau sebagai saran saja." (Rohmadiani, 2014:33)

Tanda koma dipakai di belakang kata atau ungkapan penghubung antar kalimat yang terdapat pada awal kalimat. Dapat dilihat pada kutipan diatas seharusnya setelah kata oleh karena itu diberi tanda baca koma sebagai tanda pemisah, karena konjungsi Oleh karena itu merupakan aposisi dari kata yang 
diterangkannya. Sehingga penulisan yang sesuai dengan EYD ialah "Oleh karena itu, peran masyarakat disini hanya clients atau sebagai saran saja."

\section{SIMPULAN}

Berdasarkan hasil penelitian dan pembahasan dalam Kesalahan Pemakaian Tanda Baca Pada Wahana FKIP Volume 62 Nomor 1 Tahun 2014 Universitas PGRI Adi Buana Surabaya dapat diambil kesimpulan sebagai berikut.

Pemakaian tanda baca dalam ejaan bahasa indonesia yang disempurnakan mencakup pengaturan (1) tanda titik, (2) tanda koma, (3) tanda titik koma, (4) tanda titik dua, (5) tanda hubung, (6) tanda pisah, (7) tanda elipsis, (8) tanda tanya, (9) tanda seru, (10) tanda kurung, (11) tanda kurung siku, (12) tanda petik, (13) tanda petik tunggal, (14) tanda ulang, (15) tanda garis miring. Terdapat 64 kesalahan dalam pemakaian tanda baca wahana FKIP Universitas PGRIAdi Buana Surabaya yang dianalisis atau yang dibahas pada bab 4. Tetapi dalam pembahasan hanya difokuskan pada pemakaian tanda baca titik (.), tanda koma (,), tanda titik dua (:), tanda hubung (-), tanda kurung $(())$, tanda garis miring $(/)$.

\section{SARAN}

Berdasarkan penelitian, penulis memberi saran sebagai berikut:

1. Penelitian ini merupakan penelitian tahap awal sehingga masih terdapat banyak kekurangan dan masih memerlukan tindak lanjut. Oleh karena itu, diharapkan muncul peneliti lain yang akan mengembangkan penelitian ini.

2. Penelitian terhadap wahana FKIP Universitas PGRI Adi Buana Surabaya dapat dilakukan dengan berbagai tinjauan lain, yang mampu memperjelas makana pada ujaran yang dituturkan. Sehingga penulisan atau penelitian tersebut dapat bermanfaat bagi orang lain.

\section{DAFTAR PUSTAKA}

Alek dan Akhmad. 2010. Bahasa Indonesia Untuk Perguruan Tinggi. Jakarta: Kencana.

Budiono, Sunu Catur, dkk. Pedoman Penulisan Skripsi Dan Artikel Ilmiah. Surabaya.

Finoza, Laminuddin. 2005. Komposisi Bahasa Indonesia. Jakarta: Diksi dan Insan Mulia.

Keraf, Gorys. 1964. Tata Bahasa Indonesia. Jakarta: Nusa Indah.

Moleong, Lexy J. 2000. Metodologi Penelitian Kualitatif. Bandung: PT Remaja Rosdakarya.

Muslich, Mansyur. 2010. Garis-Garis Besar Tata Bahasa Baku Bahasa Indonesia. Bandung: Refika Aditama.

Pamungkas, Sri. 2012. Bahasa Indonesia Dalam Berbagai Perspektif. Yogyakarta: Andi

Rahardi, Kunjana. 2009. Bahasa Indonesia Untuk Perguruan Tinggi. Jakarta: Erlangga.

Sugiyono. 2013. Motede Penelitian Kualitatif, Kuantitatif dan R\&D. Bandung: Alfabeta.

2012. Pedoman Umum Ejaan Bahasa Indonesia Yang Disempurnakan dan Pedoman Umum Pembentukan Istilah. Surabaya: Palito Media. 